\title{
SUPT5H Gene
}

National Cancer Institute

\section{Source}

National Cancer Institute. SUPT5H Gene. NCI Thesaurus. Code C18389.

This gene is involved in both positive and negative regulation of transcriptional elongation. It also plays a role in the modification of chromatin. 